\title{
Correction to: The Potential Role of miRNAs as Predictive Biomarkers in Neurodevelopmental Disorders
}

\author{
Iman Imtiyaz Ahmed Juvale ${ }^{1} \cdot$ Ahmad Tarmizi Che Has $^{1}$ (D)
}

Published online: 15 May 2021

๑) Springer Science+Business Media, LLC, part of Springer Nature 2021

\section{Correction to: Journal of Molecular Neuroscience https://doi.org/10.1007/s12031-021-01825-7}

The original version of this article unfortunately contained mistakes in the References section. The bibliographic entries of "Chandley et al. 2015; Ciaccio et al. 2017; Curatolo et al. 2014; Frye et al. 2017; Green et al. 2019; Hamed et al. 2015; Huntley et al. 2012; Mor et al. 2015; Nakata et al. 2019; Novotny et al. 2018; Ornoy and Spivak 2019; and Pagliaroli et al. 2020" were incomplete. The updated references are presented below:

\section{References}

Chandley M, Crawford J, Szebeni A, Szebeni K, Ordway G (2015) NTRK2 expression levels are reduced in laser captured pyramidal neurons from the anterior cingulate cortex in males with autism spectrum disorder. Mol Autism 6:28. https://doi.org/10.1186/ s13229-015-0023-2

Ciaccio C, Fontana L, Milani D, Tabano S, Miozzo M, Esposito S (2017) Fragile $X$ syndrome: a review of clinical and molecular diagnoses. Ital J Pediatr 43(1):39. https://doi.org/10.1186/ s13052-017-0355-y

Curatolo P, Ben-Ari Y, Bozzi Y, Catania MV, D’Angelo E, Mapelli L, Oberman LM, Rosenmund C, Cherubini E (2014) Synapses as therapeutic targets for autism spectrum disorders: an international symposium held in Pavia on July 4th, 2014. Front Cell Neurosci 8:309. https://doi.org/10.3389/fncel.2014.00309

Frye RE, Wynne R, Rose S, Slattery J, Delhey L, Tippett M, Kahler SG, Bennuri SC, Melnyk S, Sequeira JM, Quadros EV (2017) Thyroid dysfunction in children with autism spectrum disorder is associated with folate receptor $\alpha$ autoimmune disorder. J Neuroendocrinol 29(3). https://doi.org/10.1111/jne.12461

The original article can be found online at https://doi.org/10.1007/ s12031-021-01825-7

\section{Ahmad Tarmizi Che Has}

ahmadtarmizi@usm.my

1 Department of Neurosciences, School of Medical Sciences, Universiti Sains Malaysia, Health Campus, 16,150 Kubang Kerian, Kelantan, Malaysia
Green RM, Travers AM, Howe Y, McDougle CJ (2019) Women and autism spectrum disorder: diagnosis and implications for treatment of adolescents and adults. Curr Psychiatry Rep 21(4):22. https://doi.org/10.1007/s11920-019-1006-3

Hamed AM, Kauer AJ, Stevens HE (2015) Why the diagnosis of attention deficit hyperactivity disorder matters. Front Psychiatry 6:168. https://doi.org/10.3389/fpsyt.2015.00168

Huntley Z, Maltezos S, Williams C, Morinan A, Hammon A, Ball D, Marshall EJ, Keaney F, Young S, Bolton P, Glaser K, HoweForbes R, Kuntsi J, Xenitidis K, Murphy D, Asherson PJ (2012) Rates of undiagnosed attention deficit hyperactivity disorder in London drug and alcohol detoxification units. BMC Psychiatry 12:223. https://doi.org/10.1186/1471-244X-12-223

Mor M, Nardone S, Sams DS, Elliott E (2015) Hypomethylation of miR-142 promoter and upregulation of microRNAs that target the oxytocin receptor gene in the autism prefrontal cortex. Mol Autism 6:46. https://doi.org/10.1186/s13229-015-0040-1

Nakata M, Kimura R, Funabiki Y, Awaya T, Murai T, Hagiwara M (2019) MicroRNA profiling in adults with high-functioning autism spectrum disorder. Mol Brain 12:82. https://doi.org/10. 1186/s13041-019-0508-6

Novotny M, Valis M, Klimova B (2018) Tourette syndrome: a minireview. Front Neurol 9:139. https://doi.org/10.3389/fneur.2018. 00139

Ornoy A, Spivak A (2019) Cost effectiveness of optimal treatment of ADHD in Israel: a suggestion for national policy. Health Econ Rev 9:24. https://doi.org/10.1186/s13561-019-0240-z

Pagliaroli L, Vereczkei A, Padmanabhuni SS, Tarnok Z, Farkas L, Nagy P, Rizzo R, Wolanczyk T, Szymanska U, Kapisyzi M, Basha E, Koumoula A, Androutsos C, Tsironi V, Karagiannidis I, Paschou P, Barta C (2020) Association of genetic variation in the 3'UTR of LHX6, IMMP2L, and AADAC with Tourette syndrome. Front Neurol 11:803. https://doi.org/10.3389/fneur.2020.00803

The original article has been corrected.

Publisher's Note Springer Nature remains neutral with regard to jurisdictional claims in published maps and institutional affiliations. 